\title{
The Primates 2014 Most-Cited Paper Award is conferred upon Dr. Goro Hanya et al.
}

(C) Japan Monkey Centre and Springer Japan 2014

The paper by Dr. Goro Hanya, (with Dr. Nelly Ménard, Dr. Mohamed Qarro, Dr. Mohamed Ibn Tattou, Dr. Mieko Fuse, Dr. Dominique Vallet, Dr. Aya Yamada, Dr. Moe Go, Dr. Hino Takafumi, Dr. Riyou Tsujino, Dr. Naoki Agetsuma, Dr. Kazuo Wada) titled "Dietary adaptations of temperate primates: comparisons of Japanese and Barbary macaques" (Hanya et al. 2011) was cited most frequently in 2013 among those published in Primates during the term from 2011 to 2012. Their work thus contributed greatly to enhancing the reputation of our journal. For this achievement, Dr. Hanya will receive gifts from the Japan Monkey Centre, the Primate Society of Japan and Springer.

27 July, 2014

Tetsuro Matsuzawa: Executive Director, Japan Monkey Centre

Juichi Yamagiwa: Editor-in-Chief, Primates

Keiko Shimizu: President, Primate Society of Japan

Koji Yamashita: President and Managing Director, Springer Japan

\section{Reference}

Hanya G, Ménard N, Qarro M, Tattou MI, Fuse M, Vallet D, Yamada A, Go M, Takafumi H, Tsujino R, Agetsuma N, Wada K (2011) Dietary adaptations of temperate primates: comparisons of Japanese and Barbary macaques. Primates 52:187-198 